\title{
Jesuit Pacifism: The Conversion of Daniel Berrigan
}

\author{
Daniel Cosacchi \\ Department of Religious Studies, Marywood University, Scranton, PA, USA \\ dcosacchi@marywood.edu
}

\begin{abstract}
Among the Catholics who grew to prominence in the twentieth century, few matched the public witness of Daniel Berrigan (1921-2016). This paper will develop the topic of Berrigan's use of the Spiritual Exercises of St. Ignatius as the backbone of his pacifism. This paper's approach will be threefold. First, it expands on the sparse scholarly work on Berrigan specifically as a Jesuit and a priest. Second, it examines Berrigan's own conversion alongside Ignatius's dramatic decision to lay down his weapons in Montserrat. Third, in light of this momentous development in Ignatius's life, the article will examine whether such pacifism ought to be mandatory for Jesuits today (beyond the prohibition on clerics from bearing arms in warfare), taking the particular case of Berrigan and his triumphs and trials into consideration as an example.
\end{abstract}

\section{Keywords}

Daniel Berrigan - peacemaking - nonviolence - war - conversion - discernment military chaplains - Spiritual Exercises

When Daniel Berrigan died on April 30, 2016 at the age of ninety-four, the Catholic peace movement lost a towering figure among their number. Many casual observers of Berrigan's life and work might have assumed that he had long been dismissed from his religious order - the Society of Jesus-because of his many arrests. Even though Berrigan was often a gadfly to both his religious superiors and the Catholic hierarchy in the United States, he remained a priest and Jesuit in good standing until his death. Nevertheless, those who were under the impression he had left the order had good reason to think so. In 1993, more than twenty-five years after he was the public face of a group of 
nine Catholic peace activists who burned draft files with homemade napalm in Catonsville, Maryland, Berrigan wrote in a letter to his brother Philip (also a member of the "Catonsville 9" and who had left the priesthood), "They [the Jesuits] almost kicked me into outer darkness after Catonsville." Even if he was not dismissed outright from the Jesuits, he was unceremoniously evicted from his Jesuit residence on the very day he was released from federal prison in 1972: "[Berrigan] arrived late that night at his apartment at Fordham University, only to find that all his possessions had been removed and dumped in the hall and his door had been locked."2 Nevertheless, in his later years he would claim that his decision to join the Jesuits was among the most important decisions of his life. When he was asked in 2009 what he was most grateful for in his life, he replied, "My Jesuit vocation." ${ }^{3}$

This paper will focus on three areas of Berrigan's formation and activism. First, it will consider Berrigan's life in the Jesuit order and as an ordained priest. What impact did religious life have on his thought? How did he consider his role as a minister of the church's sacraments to be related to his work in the peace movement? Secondly, the paper will focus on the conversion experiences of Berrigan and the founder of his order, Ignatius of Loyola (c.1491-1556). In both instances, the conversion experience led to a life of renouncing violence; however, these respective conversions led the two men in different directions. Ignatius turned over his weapons, and Berrigan engaged in civil disobedience against war. Third, the paper will examine the role of Jesuits in peacemaking through the lens of Berrigan's bold and faithful, but some might say extreme, witness. Ought it be mandatory for Jesuits to work for the cessation of all violence, even if that work takes them to prison? Should that particular apostolate be an institutional priority for the Society of Jesus? Throughout this paper, I will treat the Spiritual Exercises of Ignatius ${ }^{4}$ as a guiding light for Berrigan's motivations in his activism and writings.

1 Daniel Cosacchi and Eric Martin, eds. The Berrigan Letters: Personal Correspondence between Daniel and Philip Berrigan (Maryknoll, NY: Orbis Books, 2016), 268.

2 Murray Polner and Jim O'Grady, Disarmed and Dangerous: The Radical Life and Times of Daniel and Philip Berrigan, Brothers in Religious Faith and Civil Disobedience (Boulder, CO: Westview Press, 1997), 262.

3 George Anderson, "Looking Back in Gratitude: A Conversation with Daniel Berrigan," America 201, no. 1 (July 6, 2009): 25-27, at 25 .

4 St. Ignatius of Loyola and Louis J. Puhl, S.J., The Spiritual Exercises of St. Ignatius: A New Translation Based on Studies in the Language of the Autograph (Westminster, MD: Newman Press, 1954). 


\section{Berrigan as Jesuit and Priest}

When Berrigan entered the Jesuits on August 14, 1939, and even when he was ordained to the Catholic priesthood on June 21, 1952, there was no real indication that he would make any waves either in his religious order or in the Catholic world writ large. It seemed likely that he would become a Scripture scholar, having been assigned to a tenure-track position at Le Moyne College in 1957, which was the same year his book Time without Number was awarded the Lamont Prize for Poetry. By 1954, however, Berrigan had undergone a conversion of sorts while living in France for his tertianship year, and this conversion indelibly shaped both his membership in the Jesuits and his priesthood overall. ${ }^{5}$

What was Berrigan's understanding of membership in a religious order? For all of the emphasis on the traditional vows of poverty, chastity, and obedience in the Society of Jesus, the heart of Berrigan's vocation was friendship. He claims to have entered the order because his high school friend, Jack St. George, had also entered. As Berrigan describes it, "But for [Jack], I would be sporting a far different cap and gown today; or none at all. My half-century in the Jesuits is due, under God, to him."6 There are parallels here between these two friends and the seven men who were the original Jesuits, or as they described themselves, "friends in the Lord." And yet, some of the relationships Berrigan would form in the Jesuits would take place amidst "awesome ironies": "A consuming passion for the perfect, embraced by the newly converted Ignatius (himself plucked from a very pit of imperfection) — and then, the vision of perfection transposed to a rule of life, on the all too imperfect!"8 Or, even more concretely, Berrigan writes of his philosophy studies, "I cannot, for the life of me, summon a single redeeming feature of those three years, at pain of being dishonest or trifling." These passages are only two of many from

5 Tertianship is a part of Jesuit formation that normally takes place after the individual has been ordained to the priesthood. It is a third year that completes the formation, which began with the two-year novitiate.

6 Daniel Berrigan, To Dwell in Peace: An Autobiography (New York: Harper and Row, 1987), 81.

7 See John W. O'Malley, The First Jesuits (Cambridge, MA: Harvard University Press, 1993), 28-32 and O'Malley, The Jesuits: A History from Ignatius to the Present (Lanham, MD: Rowman and Littlefield, 2014), 1-4.

8 Berrigan, To Dwell in Peace, 103. This passage is only one of many in the chapter entitled "The Jesuits: For Life" that describe a period of formation that would be a difficult time for Berrigan. While he would appreciate it in some regards, such as preparation for life in prison, ultimately one would have to conclude this was not a pleasant time in Berrigan's life.

9 Berrigan, To Dwell in Peace, 104. 
Berrigan's writings describing a period of formation that he clearly resented in many ways, despite the commitments he felt to his order and his brethren.

Friendship was not only among Berrigan's most integral personal characteristics ${ }^{10}$ but it was a theological foundation for him that served as a bedrock in his decision to remain a Jesuit." Moreover, what Ignatius of Loyola called "mutual union" is an essential part of the Jesuit charism. ${ }^{12}$ Berrigan's deepest engagement with friendship appears in his book Portraits of Those I Love, which he describes in the opening line of the text as "a tribute to friendship."13 Interestingly, he also reflects on friendship specifically as someone who is a priest: "friendship is also a chief delight of the celibate life."14 Furthermore, friendship is not something limited to this life. Of Peter Maurin (1877-1949), the co-founder of the Catholic Worker Movement, Berrigan writes of friendship with a man whom he never met. Though this is "a circumstance that may appear inhibiting to friendship," Berrigan reminds the reader that "most of us have yet to pass a time of incubating love with various admired mentors, peers, gurus, saviors, opposite numbers. Something still awaits, we are promised, under another sky, and we in a more serviceable frame than 'the body of this death."'15 Friendships with both Jesuit and not, ordained and lay, Catholic and not, gay and straight, family and enemy, are absolutely essential to Berrigan's understanding of the religious life.

Berrigan is also clear that preparation for martyrdom is an essential part of the priesthood. Among his Jesuit confrères, he admires few as deeply as the Salvadoran martyrs of the University of Central America, who were assassinated along with their housekeeper and her daughter by their country's United States-trained military on November 16, 1989. Berrigan reflects on the parallel vocations of the priest and the martyr: "An ordination photo of the murdered

10 See Jim Forest, At Play in the Lions' Den: A Biography and Memoir of Daniel Berrigan (Maryknoll, NY: Orbis Books, 2017).

11 See Daniel Berrigan, Portraits of Those I Love (New York: Crossroad, 1982).

12 See Constitutions of the Society of Jesus, no. 655. Avery Dulles (1918-20o8) elaborated on this point, naming mutual union as one of the ten guiding principles of the Society of Jesus, along with dedication to the glory of God, personal love for Jesus Christ and a desire to be counted among his close companions, laboring with, in and for the Church, availability, a preference for spiritual and priestly ministries, discernment, adaptability, respect for human and natural capacities, and an original synthesis of the active and contemplative life. See Avery Dulles, "The Ignatian Charism at the Dawn of the Twenty-First Century," in Church and Society: The Laurence J. McGinley Lectures, 1988-2007 (New York: Fordham University Press, 2008), 500-2.

13 Berrigan, Portraits of Those I Love, 7.

14 Berrigan, Portraits of Those I Love, 7.

15 Berrigan, Portraits of Those I Love, 9. 
Jesuit Ignacio Ellacuría shows him prostrate on the sanctuary floor while the litany of saints is chanted. A photo dated Thursday, November 16, 1989, shows him murdered outside the Jesuit house in San Salvador. His body is prostrate, face down. It is exactly the position of his ordination rite."16 The true measure of the sacrament of Holy Orders, for Berrigan, is how closely one allies himself with God's Word over and against the word of present culture. Therefore, sacramental priesthood becomes a countercultural lifestyle, not especially in the sense of celibacy, but rather in the priest distancing himself from contemporary idols. And the price to pay is significant: "Those who dare stand for something, or stand in the way, are cut down. Those who speak concretely about political malfeasance, military violence, corporate greed, who in sum confess to an aversion against murder, however legally sanctioned, are dealt with, and not gently."17 It is clear that the martyrdom of Berrigan's Latin American brethren (and many others) influenced him. Or, as he puts it in a 1971 letter to young Jesuits, "The saving of lives is, I take it, our business, even to the point of laying down our own."18

Berrigan's understanding of himself precisely as a Jesuit priest can be traced to his prayer as it was shaped by the Spiritual Exercises, though it is evident that there was a tension in Berrigan's level of comfort in the Jesuit order. While he was clearly uncomfortable with the rigidness of the early stages of his Jesuit formation, there were also things that appealed to him about the Jesuit life: "I think they gave me a deep sense of the presence of God in the world, and most especially in human community. I must say too that I fell in love immediately and incurably with the Jesuit style."19 That same style Berrigan also considered impeding his freedom and autonomy at times. For example, the Jesuit style also includes obedience to superiors. In 1965, a young Catholic Worker named Roger LaPorte (1943-65) immolated himself in New York City in order to protest US involvement in the Vietnam War. After learning of that news, Berrigan explains, "The next message, from my superior, arrived in tones of absolute panic. I was, under no circumstance, to issue a public statement regarding the young man's death." ${ }^{20}$ In response, Berrigan preached in LaPorte's memory at

16 Daniel Berrigan, Whereon to Stand: The Acts of the Apostles and Ourselves (Baltimore: Fortkamp Publishing, 1991), 234.

17 Daniel Berrigan, Testimony: The Word Made Fresh (Maryknoll, NY: Orbis Books, 2004), 112.

18 Daniel Berrigan, America Is Hard to Find: Notes from the Underground and Letters from Danbury Prison (New York: Doubleday, 1972), 132.

19 Daniel Berrigan, No Bars to Manhood (New York: Doubleday, 1968), 4.

20 Berrigan, To Dwell in Peace, 180. 
the Eucharist offered the day after LaPorte died.$^{21}$ For decades, the story had gone that the archbishop of New York, Cardinal Francis Spellman (1889-1967; in office 1939-67) had made the decision to "exile" Berrigan to Latin America. This account was refuted as early as 1981 by James Hennesey, S.J. (1926-2001), who was the assistant to the provincial at the time of the decision. ${ }^{22}$ Only in recent years has the record been corrected exhaustively to identify Berrigan's Jesuit superior, John McGinty, S.J. (1913-76; in office 196o-66), as solely responsible for Berrigan's exile to Latin America. ${ }^{23}$ In this particular case, Berrigan went nearly forty years without even knowing that he was punished by his own order.

Berrigan's writings evince an inspired understanding of Ignatius's Spiritual Exercises and the "Jesuit style" that kept Berrigan in the order for the entirety of his adult life. When Berrigan first made the Exercises as a young novice in the order, key Christological questions arose for him: "Who indeed was this Christ, who was He to us, to our generation? Who was He to technology and superpower politics and world wars? What did He have to say, to deny, to excoriate, to rejoice in, given such a world as ours?"24 Moreover, he eventually connected this desire to know Christ more deeply to his growing understanding of the immorality of war, asking as well, "Did Christ, to the point, if point there was, curse or rejoice in the carnage of the war? And if he rejoiced, what of us? And if he cursed, what then?"25

Berrigan's understanding of his vocation as a Jesuit priest trying to emulate the example of Christ, who not only saved lives but gave his own, can be read in the context of the three kinds of humility that Ignatius discusses as a topic for prayer in the second week of the Exercises. In that particular exercise, Ignatius explains the first kind of humility as the minimum requirements for salvation: "As far as possible I so subject and humble myself as to obey the law of God our Lord in all things [...] [never] to consent to violate a commandment, whether

21 See John Dear, ed., Daniel Berrigan: Essential Writings (Maryknoll, NY: Orbis Books, 2009), 65-73.

22 See James Hennesey, American Catholics: A History of the Roman Catholic Community in the United States (Oxford: Oxford University Press, 1981), 319.

23 See Rodger Van Allen, "What Really Happened?: Revisiting the ${ }_{1965}$ Exiling to Latin America of Daniel Berrigan, S.J.," in American Catholic Studies 117, no. 2 (Summer 2006): 33-6o.

24 Berrigan, To Dwell in Peace, 104.

25 Berrigan, To Dwell in Peace, 104. It must also be noted that the precise questions Berrigan asks about warfare were likely later reflections because on the very next page of To Dwell in Peace, he readily admits that he had not entertained the question of war's morality until a few years later. Nevertheless, the Christological questions remain as key in Berrigan's formation. 
divine or human, that binds me under pain of mortal sin" [no. 165]. ${ }^{26}$ Moving upwards on the hierarchy of the kinds of humility, Ignatius explains the second kind of humility as more stringent than the first:

I neither desire nor am inclined to have riches rather than poverty, to seek honor rather than dishonor, to desire a long life rather than a short life, provided only in either alternative I would promote equally the service of God our Lord and the salvation of my soul [...]. This second kind of humility supposes that not for all creation, nor to save my life, would I consent to commit a venial sin [no. 166].

The third, and "most perfect," form of humility presupposes the first two and goes a step further:

In order to imitate and be in reality more like Christ our Lord, I desire and choose poverty with Christ poor, rather than riches; insults with Christ loaded with them, rather than honors; I desire to be accounted as worthless and a fool for Christ, rather than to be esteemed as wise and prudent in this world. So Christ was treated before me [no. 167].

It is to this final form of humility that Berrigan aspired, especially knowing the culture in which he was writing and performing his actions of civil disobedience. The United States is not forgiving to those who are considered to be opposed to participation in warfare; oftentimes, there is an immediate accusation that this type of individual is a traitor or simply lacks patriotism. In a very real way, one who takes on the viewpoints that Berrigan espoused is often considered "worthless and a fool for Christ." Berrigan, however, went through a conversion that led him to this form of humility.

\section{Conversion: Ignatius and Berrigan}

It is undeniable that Ignatius and Berrigan both went through conversion experiences in their lives. On a fundamental level, both individuals believed that constantly experiencing conversion is fundamental to the life of Christian discipleship. The Spiritual Exercises are, themselves, a manual on how the

26 All citations from The Spiritual Exercises will be taken from the Puhl edition noted above. Henceforth, they will be cited within the text using the paragraph number of the exercise in brackets. 
Christian and even non-Christians have gone through radical conversion experiences. ${ }^{27}$ But even more to the point, instances of specific conversions were crucial to both Ignatius and Berrigan, and subsequently shaped the remainder of their lives and their respective influences on the world. The opening lines of the so-called autobiography Ignatius told his confrère Luís Gonçalves da Câmara ${ }^{28}$ narrate a tale of a wayward (or at least, worldly) soul: "Up to his twenty-sixth year he was a man given to worldly vanities, and having a vain and overpowering desire to gain renown, he found special delight in the exercise of arms." ${ }^{29}$ In May of 1521, Ignatius's legs were severely injured by a cannonball while in the service of the duke of Nájera in an attack by the French on Pamplona. This began a ten-month convalescence in Loyola, until March 1522, which culminated in one of the most famous conversions in Christian history. One symbol of Ignatius's conversion is particularly significant for Berrigan's own fate. On March 24, 1522, Ignatius deposited "his sword and dagger at our Lady's altar in the church" in Montserrat. ${ }^{30}$

Not every conversion has a "cannonball moment," however. Often, conversion occurs over years or decades. The Spiritual Exercises, written by one who underwent a conversion himself, are framed as a manual in how to pray so as to inspire one's own conversion of heart. Likewise, when it is experienced in a profound way by the exercitant, the Spiritual Exercises can lead to a conversion in their lives as well. In particular, Berrigan's thirty-day retreat in 1954 changed his life and ministry permanently. Of conversion, Bernard Lonergan writes,

[We achieve] authenticity in self-transcendence [...]. Our capacity for self-transcendence $[\ldots]$ becomes an actuality when one falls in love. Then one's being becomes being-in-love [...]. Once it has blossomed forth and as long as it lasts, it takes over. It is the first principle. From it flow one's desires and fears, one's joys and sorrows, one's discernment of values, one's decisions and deeds. ${ }^{31}$

27 See Roger Haight, Christian Spirituality for Seekers: Reflections on the Spiritual Exercises of Ignatius Loyola (Maryknoll, NY: Orbis Books, 2012).

28 See Joseph N. Tylenda, S.J., ed. A Pilgrim's Journey: The Autobiography of Ignatius of Loyola, rev. ed. (San Francisco: Ignatius Press, 2001), 7-10 and 29-36.

29 Tylenda, A Pilgrim's Journey, 37 [Autobiography, no. 1]. In fact, as Tylenda notes in his commentary note 1 on page 37 of this text, Ignatius was actually closer to thirty years old at the time of the events in question, not twenty-six as he would have told Câmara.

30 Tylenda, A Pilgrim's Journey, 62 [Autobiography, no. 17].

31 Bernard Lonergan, Method in Theology (Toronto: University of Toronto Press, 199o), 105. 
Such a conversion experience toward love for Berrigan began during his tertian year of $1953^{-54}$ in France. In that year, Berrigan would have as the director of his retreat Père François Charmot (1881-1965), who would come to be an instrumental character in Berrigan's spiritual life. Berrigan would later refer to him as "the best and tenderest of masters." ${ }^{2}$ The retreat with Charmot affected Berrigan much more profoundly than did his first thirty-day silent retreat a decade earlier: "It had taken Charmot ten days to shake our world, persistent as he was, and vigilant, and no more disposed than Ignatius to let us off lightly." ${ }^{33}$ But what would be the explicit manifestation of this conversion? Before making this retreat, Berrigan had been a supporter of the works of war, even encouraging his brother Philip in his life in the military as parallel to his own life in the seminary, referring to Christ in a 1943 letter as "Him Who was a good Soldier - unto death." ${ }^{44}$ Two years later, Berrigan hosted that same brother at the Jesuit seminary in Woodstock, Maryland, upon Philip's triumphant homecoming from the recently concluded World War II. Philip Berrigan describes the scene: "We sang, toasting the war's end, patting ourselves on the back. There were many men in uniform, but I was the only officer so I carried the flag as we marched around the main building - a couple of platoons of soldiers, two hundred Jesuits, friends, family, kids - all cheering our country's victory, congratulating ourselves." ${ }^{35}$ Only twenty-two years later, these Berrigan brothers who had once embraced and celebrated war would be burning United States draft files with homemade napalm. How did that happen? It first began in France during the Spiritual Exercises, which Berrigan described as "an invitation to become a human being by way of others, immersed as we all were during that year in the tradition of our scripture, as well as the experience and history of our Order." ${ }^{36}$ And so the seeds were planted for his long conversion.

In the same way that, as Berrigan attests, Charmot had shaken his world, so too did the wartime experience of his brother Philip also shake him. Reflection on that experience slowly turned Philip toward a religious vocation (he entered the Josephites for a time) and a life of working in the peace movement. But, for Dan, that alone would not be sufficient to lead him down the same path. In February of 1968, he accompanied the historian Howard Zinn to Hanoi to

\footnotetext{
32 Berrigan, To Dwell in Peace, 127.

33 Berrigan, To Dwell in Peace, 128.

34 Letter of Daniel Berrigan to Philip Berrigan, September 15, 1943, cited in Cosacchi and Martin, eds., The Berrigan Letters, 7.

35 Philip Berrigan with Fred A. Wilcox, Fighting the Lamb's War: Skirmishes with the American Empire (Monroe, ME: Common Courage Press, 1996), 22.

36 Berrigan, No Bars to Manhood, 5 .
} 
negotiate the release of three American fighter pilots. ${ }^{37}$ Then, two months later, Philip visited him at Cornell to invite him to take part in the Catonsville action of burning the draft files. Dan explains the process of deciding to undertake this action: "In true Jesuit fashion, I said 'Well give me a couple of days because I want to put down the 'pros' and 'cons' and have some meditative time.' [...] I did my discernment, and much to my chagrin, the 'pros' outweighed the 'cons.' [...] Though that kind of simplifies it that's what happened."38 Berrigan is noting another significant aspect of the Spiritual Exercises and the life of any Jesuit: the reality of the process of discernment in making any decision. While conversions are experiences of the heart, they involve an intellectual level as well. In this part of Berrigan's conversion, there was an absolute dependence on reflecting on reality.

The process of Ignatian discernment is at the very heart of the Spiritual Exercises. One of the key mistakes that is frequently made concerning discernment is that the process entails making decisions between good and bad alternatives. In fact, Ignatian discernment is between two goods. In Berrigan's case, deciding to engage in nonviolent civil disobedience in Catonsville was a major decision. Another Jesuit who utilized the gift of discernment that he had learned in his formation was Dean Brackley, S.J. (1946-2011), who succeeded the Jesuits of the University of Central America in El Salvador after they were brutally murdered in 1989. Brackley explains, "Even though feeding the hungry, housing the homeless, and defending the weak are strict moral demands and not optional acts of 'charity,' we are not obliged to feed and house every hungry and homeless person within reach." ${ }^{39}$ The art of discernment can lead to people being able to discover their vocation in life and so to act upon it. Absolutely essential in any authentic Ignatian discernment is the final step, which leads the individual to take action. ${ }^{40}$ Berrigan's discernment led him to accept gospel nonviolence as an absolute way of life. Furthermore, however, his discernment moved him to work for peace in a concrete way. In a letter dated April 10, 1970 to his brother Jesuits, Berrigan openly wonders whether he or they can place

37 See Daniel Berrigan, Night Flight to Hanoi: War Diary with 11 Poems (New York: Macmillan, 1968); Forest, At Play in the Lions' Den, 111-15.

38 Anna J. Brown and James L. Marsh, "A Conversation with Daniel Berrigan," in James L. Marsh and Anna J. Brown, eds., Faith, Resistance, and the Future: Daniel Berrigan's Challenge to Catholic Social Thought (New York: Fordham University Press, 2012), 288.

39 Dean Brackley, S.J., The Call to Discernment in Troubled Times: New Perspectives on the Transformative Wisdom of Ignatius of Loyola (New York: Crossroad, 2004), 129.

40 See Timothy M. Gallagher, O.M.V., The Discernment of Spirits: An Ignatian Guide for Everyday Living (New York: Crossroad, 2005), 24. 
their trust in the leaders of the institutional church: "No, we must begin again, where we live. The real question of the times is not the conversion of cardinals and presidents, but the conversion of each of us." ${ }^{31}$ Part of Berrigan's reason for writing the letter is to report his decision to go "underground" and evade the FBI. In this scathing letter, Berrigan pulls no punches with the hierarchy or with his Jesuit brethren. Ignatian discernment played a role in all of these conclusions at which Berrigan arrived in his role as agitator par excellence; his conversion, paradoxically, made it harder (in some ways) for him to be a Jesuit even as it resulted from his powerful embrace of Ignatian principles and the practice of praying through the Spiritual Exercises during his 1954 retreat.

It should be noted that there is one paragraph of the Constitutions of the Society of Jesus that is especially interesting considering Berrigan's proclivities to work for nonviolence in the world. Ignatius writes that Jesuits ought to work to fulfill the corporal works of mercy, "to the extent that the more important spiritual activities permit and their own energies allow; for example [...] by the reconciliation of quarreling parties." ${ }^{\text {22 }}$ The question remains: How did Berrigan engage in reconciling quarreling parties, given his bold activism? Furthermore, could Berrigan justify the ministry of Jesuit military chaplains and Jesuit scholars who upheld the just war principles? In the former case, Berrigan's ministry of reconciliation could well have been between groups who often find themselves on opposite ends of ideological battles over "life" issues. Berrigan broke down the walls of separation between folks who supported abortion rights, but not war or the death penalty, or vice versa. Berrigan's ministry of reconciliation was such that he saw it as a possible outcome of integral work on behalf of the dignity of the human person that sometimes-opposed factions might come together in a common cause. On the latter question, however, I must admit that Berrigan seems more like a wedge in a religious congregation that includes both pacifists and military chaplains. Nevertheless, it is also possible that peacemaking might be considered a "more important spiritual activity" that would not have allowed for reconciliation with military chaplains. Some people, in other words, could have occupations or even ministries that were simply not in accordance with the gospel, even if they were sanctioned by a given religious community or superior.

41 Berrigan, America is Hard to Find, 36.

42 Constitutions of the Society of Jesus, no. 65o. I am indebted to Thomas Massaro, S.J. who posed these particular questions to me in citing this source. 


\section{Pacifism: Normative for Jesuits?}

The final section of this paper considers Berrigan's witness for the Jesuit order. Ought the Society of Jesus to take up Berrigan's mantle of absolute pacifism as part of its charism? Should the order's rule be modified such that all Jesuits follow in his footsteps as peacemakers in the larger society? The necessary preface to this discussion is the longstanding belief that all Roman Catholic priests have always been bound by personal obligations of nonviolence. While this was certainly an important part of Ambrose's (d.397), ${ }^{43}$ Augustine's $\left(354^{-430}\right),{ }^{44}$ and Thomas Aquinas's $\left(1225^{-74}\right)^{45}$ thinking on the issue, there is another line of thought that maintains that the two-fold ethic (one for the ordained and one for the laity) is contrary to the gospel command of nonviolence. ${ }^{46}$ These points notwithstanding, and despite the fact that clerical prohibition from fighting in war was solemnized by the Council of Chalcedon (451), the 1983 Code of Canon Law is actually silent on the matter.

In Berrigan's own absolute pacifism,${ }^{47}$ he held himself to a very demanding ethic of personal nonviolence paired with a public witness of calling the rest of society to nonviolence. "The rest of society," for Berrigan, included his Jesuit brothers and superiors. It was clear that Berrigan believed the Jesuits were deficient in living up to the calling of their founder in many areas of the faith. It is only fair to note, however, that pacifism is not part of the Jesuit charism, as

43 See Ambrose of Milan, On Duties of the Clergy, 1.35.175, cited in Louis Swift, The Early Fathers on War and Military Service (Wilmington, DE: Michael Glazier, 1983), 108: "We [clergy] are concerned with matters of the soul rather than of the body, and our activity has to do not with weapons but with peaceful deeds."

44 Letter 20.22.

45 See Thomas Aquinas, Summa Theologica, trans. Fathers of the English Dominican Province (New York: Benziger Bros., 1948), IIa IIae, q. 40, a. 2: "The first reason is a general one, because, to wit, warlike pursuits are full of unrest, so that they hinder the mind very much from the contemplation of Divine things, the praise of God, and prayers for the people, which belong to the duties of a cleric [...]. The second reason is a special one, to wit, all clerical Orders are directed to the ministry of the altar, on which the Passion of Christ is represented sacramentally... Wherefore it is unbecoming for them to slay or shed blood, and it is more fitting that they should be ready to shed their own blood for Christ, so as to imitate in deed what they portray in their ministry."

46 For the response of Francis of Assisi, see Kenneth R. Himes, O.F.M., Christianity and Political Order: Conflict, Cooptation, and Cooperation (Maryknoll, NY: Orbis Books, 2013), 324-25; for a twentieth-century response, see Eileen Egan, Peace Be With You: Justified Warfare and the Way of Nonviolence (Maryknoll, NY: Orbis Books, 2000).

47 For a helpful distinction on the types of pacifism, see David L. Clough and Brian Stiltner, Faith and Force: A Christian Debate about War (Washington, D.C.: Georgetown University Press, 2007), 44-50. 
much as Berrigan believed it should be. While he was in federal prison, following the Catonsville action, then-superior general of the Jesuits, Pedro Arrupe (1907-91; in office 1965-83), visited him. Berrigan makes it clear in his 1971 "Letter to the Young Jesuits" that while he was very touched by this visit, many questions remained in his mind:

I looked in vain after his departure for some statement relative to the war, or to Jesuit resistance. There was none, to my knowledge. Evidently [Arrupe] had conceived his visit to me as a personal chore of charity [...]. He never took up in the course of his travels in America the questions I addressed to him some four years ago, after my return from Latin America. These questions are still to the point; they touch on the complicity of Jesuit institutions with the military establishment, in university research, chaplaincies in the armed services, presence of вотс on campus, and Society investments. ${ }^{48}$

After only the briefest of perusals of websites for Jesuit institutions today, nearly fifty years later, this "complicity" still runs strong. So, how could Berrigan balance his gratitude for his Jesuit vocation with such serious misgivings about the order's priorities?

In response to this question, Berrigan proposed two possible solutions:

If indeed I am cause of bitter division among Jesuits, it would seem sensible to pursue either of two courses: (1) Let me be dismissed from the society as a troublemaker, or (2) let the issues I have written and spoken and preached about for years, and which eventually brought me to prison, be taken up by young Jesuits with the seriousness they warrant. ${ }^{49}$

In fact, neither of those alternatives has come to fruition: Berrigan died as a Jesuit and priest in good standing, and like-minded Jesuits of younger generations are either few and far between, or have been dismissed from the order. ${ }^{50}$ What is the role of the Society of Jesus today vis-à-vis the military? While the model Berrigan describes in point two above may be utopian, the reality is that the Jesuits could make vast improvements, based on the Spiritual Exercises of

48 Berrigan, America is Hard to Find, $137-38$.

49 Berrigan, America is Hard to Find, 138.

50 See Joshua J. McElwee, "John Dear, Jesuit Known for Peace Witness, Dismissed from Order," in National Catholic Reporter (Jan. 7, 2014); https://www.ncronline.org/news/justice/johndear-jesuit-known-peace-witness-dismissed-order (accessed April 10, 2020). 
their founder. In compiling a model for the Jesuits regarding pacifism, I suggest that they return to Ignatius's "rules for discernment" in the Spiritual Exercises. This could amount to an institutional conversion of the Jesuits.

In a particular way, it might be helpful for the Jesuits to discern their future by remembering the eventuality of their death. While this may sound macabre, it is actually an essential part of Ignatian discernment of spirits. One of Ignatius's rules to make a "correct and good choice of a way of life"51 asks the individual discerning between two goods "to consider what procedure and norm of action I would wish to have followed in making the present choice if I were at the moment of death" [no. 186]. For his part, Berrigan's work focused a great deal on matters of life and death. Not only were his anti-war activism and writings focused on ending what he called the forces of death, but he also committed himself to serving those who were dying of terminal illnesses. He did not hesitate to connect these two facets of his life:

Experiencing cancer is a rehearsal for the future as presently planned. Being with those dying of cancer is to be with those among whom the Bomb has already fallen, and this is a privilege. Those we care for, the experience of their sufferings, helps me find my way to the Pentagon and the White House and the places where our communities join in resistance to a future of death and cancer. ${ }^{52}$

Placing himself close to suffering, whether it be the suffering of the cancer patient or the suffering of war's victims, is part of Berrigan's explicit theological stance, in line with many liberation theologians who insist on taking the crucified victims down from their crosses..$^{53}$ In a particular way, Berrigan aligned himself in solidarity with AIDs patients, beginning in the 1980s, ministering to their physical needs. For these patients, Berrigan embodied what theologian Elizabeth Johnson refers to as the "God of overwhelming pathos whose presence enables hope even in the midst of a brutal death." ${ }^{54}$ With dying comes a

$51 \quad$ See Ignatius of Loyola and Puhl, The Spiritual Exercises, nos. 169-89.

52 John Deedy, Apologies, Good Friends': An Interim Biography of Daniel Berrigan, S.J. (Chicago: Fides/Claretian Press, 1981), 12.

53 See Ignacio Ellacuría, "The Crucified People: An Essay in Historical Soteriology," trans. Phillip Berryman and Robert R. Barr, in Michael E. Lee, ed., Ignacio Ellacuría: Essays on History, Liberation, and Salvation (Maryknoll, NY: Orbis Books, 2013), 195-224; and Jon Sobrino, The Principle of Mercy: Taking the Crucified People from the Cross (Maryknoll, NY: Orbis Books, 1994).

54 Elizabeth Johnson, Quest for the Living God: Mapping Frontiers in the Theology of God (New York: Continuum, 2007), 56. Or, as Berrigan himself puts it in his Consequences: Truth and... (New York: Macmillan, 1965): "The suffering is not narcotized; it is made bearable. 
type of clairvoyance that Berrigan considers ironic: "The dying have been freed of the spirit of death, they have renounced the cultural illness. Hands once healed became, at the end, the hands of healers." 55 This perspective of being in solidarity with the dying gave Berrigan a different way of praying Spiritual Exercise no. 186 and imagining he was on his own deathbed in making a choice.

There is yet another exercise that Ignatius suggests to the one making an important decision, and this one may elicit even more trembling than anticipating one's death. Here, Ignatius asks the individual to decide while recalling the final judgment: "I will choose now the rule of life that I would then wish to have observed, that on the day of judgment I may be filled with happiness and joy" [no. 187]. One gets the sense, in reading Berrigan, that he was constantly considering his soul (and others' souls) in his writings. As he confessed to an interviewer, while on the run from the FBI in 1971, "I believe I will be judged in accord with the attitudes I have shown, and the efforts in support of human life I have made, right here and now."56 Berrigan believed that his soul, the soul of his religious congregation, and the soul of the nation were all at stake in how they responded to matters of life and death in the world. In the Ignatian tradition in which he was formed, Berrigan constantly discerned through an eschatological lens.

On the matter of whether the Jesuits will take on Berrigan's own stance of absolute pacifism, Berrigan himself was pessimistic. He looked around and saw a system in his religious order that did not lend itself to this commitment to nonviolence. I would concur with that pessimistic stance. Much like Karl Rahner's (1904-84) own "Christian Pessimism," ${ }^{57}$ however, Berrigan's outlook was certainly not devoid of hope, which was grounded in the life, death, and resurrection of Christ. That eschatological hope, however, is buoyed by a refusal to become passive: "We want to taste the resurrection in our bones. To see if we might live in hope, instead of in the silva oscura [sic], the thicket of

And this is all the 'answer' Christianity can offer. The Person who is present, available, and merciful" (28).

55 Daniel Berrigan, Sorrow Built a Bridge: Friendship and AIDs (Baltimore: Fortkamp Publishing, 1989), 231.

56 Daniel Berrigan and Robert Coles, The Geography of Faith: Underground Conversations on Religious, Political and Social Change, rev. ed. (Woodstock, VT: Skylight Paths Publishing, 2001), 84 .

57 See Karl Rahner, "Christian Pessimism," in Theological Investigations 22, trans. Joseph Donceel (New York: Crossroad, 1991), 155-62. For an interpretation of this essay analyzing the relationship to AIDS, whose patients Berrigan ministered to faithfully, see Paul G. Crowley, S.J., "Rahner's Christian Pessimism: A Response to the Sorrow of AIDs," Theological Studies 58, no. 2 (June 1997): 286-307. 
cultural despair, nuclear despair, a world of perpetual war."58 Since the Society of Jesus will not take an official stance prohibiting the use of violent force in society, what are the reasonable alternatives?

The first, and most essential alternative is for Jesuit leadership to reimagine the religious order as a community that welcomes figures such as Berrigan. Many Jesuits are held up as exemplary models of integrity and fidelity. While Berrigan received a funeral at which his superior provincial officiated and offered many laudatory words about him, Berrigan has been summarily erased from his province's history. ${ }^{59}$ Many younger Jesuits have no idea who he was, or why his life may have been significant in their religious order, or in American Catholicism. Berrigan's example of faithfulness should be a model that Jesuits are encouraged to follow in their own lives and ministries. More to the point, pacifist Jesuits should be encouraged to put their beliefs into concrete practices-even if that means risking jail time for participating in actions of nonviolent civil disobedience. Since Jesuits take vows of obedience to their legitimate religious superiors, these superiors provincial should not hesitate to be at least as supportive of a Jesuit who wishes to protest nuclear weapons as they are of a Jesuit who volunteers to be a military chaplain.

A second reasonable alternative that Jesuits might consider would be to curtail their involvement with the military through hosting Reserve Officer Training Corps (вотс) on many of the college campuses that the order sponsors. A Jesuit, Catholic university, in choosing to align itself with вотс, must own that it chooses as well between loving one's enemies or destroying them. ${ }^{60}$ Admittedly, this would have substantial material consequences for the institutions because retreating from this association would also result in the loss of significant financial support from the United States government. A university disassociating itself from вотс need not adopt an ethic of absolute pacifism or a wholesale renunciation of the just war theory, and certainly it should not judge those who do serve in the military. Rather, in the same way that other institutions do not host RоTC programs for a variety of reasons, ${ }^{61}$

\section{$5^{8}$ Berrigan, Testimony, 225.}

59 See Arthur C. Bender, S.J., "A Brief History of the New York Province"; https://inourcompany. files.wordpress.com/2014/11/history-of-nyk-province1.pdf (accessed July 29, 2021). Despite being one of four Jesuits ever to appear on the cover of Time magazine, Berrigan does not appear in this sixty-six-page history of the regional province to which he belonged. By any standard, this is a stunning omission.

6o The "Soldier's Creed," which each nотс cadet recites, includes the following phrase: "I stand ready to deploy, engage, and destroy, the enemies of the United States of America in close combat." For the entire "Soldier's Creed," see the manual of one Jesuit institution that hosts an Rотс program, Marquette University: "On Eagles Wings"; https://www.marquette.edu/ army-rotc/documents/eagle-wings.pdf (2017), 4 (accessed April 10, 2020).

61 E.g. small size of the institution, or close proximity of another institution that hosts Rотс. 
Jesuit universities should not host them because of the gospel teaching to love one's enemies. Berrigan believes that this command is the greatest conversion of all in the Christian life: "The verb love transforms the noun enemies. The enemy is reborn by the power of love."62

Are such alternatives possible? Even though they might be unlikely, it is worth noting that the Jesuits have made radical changes before concerning their methods. For example, no longer does the Society of Jesus respond severely to heresy or seek to convert Protestants through questionable means. ${ }^{63}$ Because the church's teaching regarding violence has evolved, the Jesuit norms concerning violence ought to evolve as well. One way in which such evolution may be possible is in considering the four "Universal Apostolic Preferences" that the Jesuits have recently adopted. ${ }^{64}$ While all four of these Apostolic Preferences are important, one in particular stands out: "To walk with the poor, the outcasts of the world, those whose dignity has been violated, in a mission of reconciliation and justice." ${ }^{65}$ Within this ministry, there must be room for Jesuits who will work for the abolition of war in any number of ways.

\section{Conclusion}

It is a matter of some surprise that a religious order that reveres a converted courtier as its founder does not take pacifism as a core value of its rule. Moreover, Ignatius himself did not emphasize pacifism as such in his own construction of said rule, even suggesting in $155^{2}$ how "the Turks" might be conquered using violent force. ${ }^{66}$ In this way, he was different from Francis of Assisi (d.1226) in the founding of his religious order, and in instructing lay members of his order in the ways of nonviolence. The actions and writings of Daniel Berrigan stand as a particular witness against all types of violence, at once in fulfillment of and in spite of his vocation as a Jesuit priest. In Berrigan's case, without a profound experience of the Spiritual Exercises, it is unlikely that he would have gone through the conversion that ultimately prepared him for a life

62 Berrigan, Testimony, 59 .

63 See O'Malley, First Jesuits, 272-83.

64 See Arturo Sosa, S.J., "Universal Apostolic Preference of the Society of Jesus, 2019-20"; https://www.jesuits.global/uap/ (accessed July 29, 2021).

65 The other three are, "To show the way to God through the Spiritual Exercises and discernment"; "To accompany young people in the creation of a hope-filled future"; "To collaborate in the care of our Common Home."

66 See "Ignatius and the Turks: Two Letters from 1552," The Way 211 (July 2006): 363-78. 
committed to nonviolence. Especially through this formation in the Spiritual Exercises of Ignatius, Berrigan went through a conversion that was not meant to end with his own change of ways, but which he intended to work outward to the entire world. Even though the Jesuit order will not be taking up an institutional position of pacifism anytime soon, I do earnestly hope that Berrigan's witness may be commended to members of the order as one way of living out the Jesuit vocation. Perhaps that radical shift in the order's priorities today will bring us one step closer to a peaceful world.

\section{Acknowledgements}

I wish to thank my erstwhile colleagues at Fairfield University for their helpful comments on this essay. I am especially grateful for the suggestions of Paul Lakeland, John Slotemaker, and John Thiel. Furthermore, an earlier version of this paper was delivered at the 2019 Catholic Theological Society of America Annual Convention. I am thankful for the comments of my fellow panelist Eric Martin, and our respondent Roger Haight, S.J. I am also thankful for the comments of those who attended the session, especially Thomas Massaro, S.J. who provided the very helpful Ignatian source found above in note 42 . 